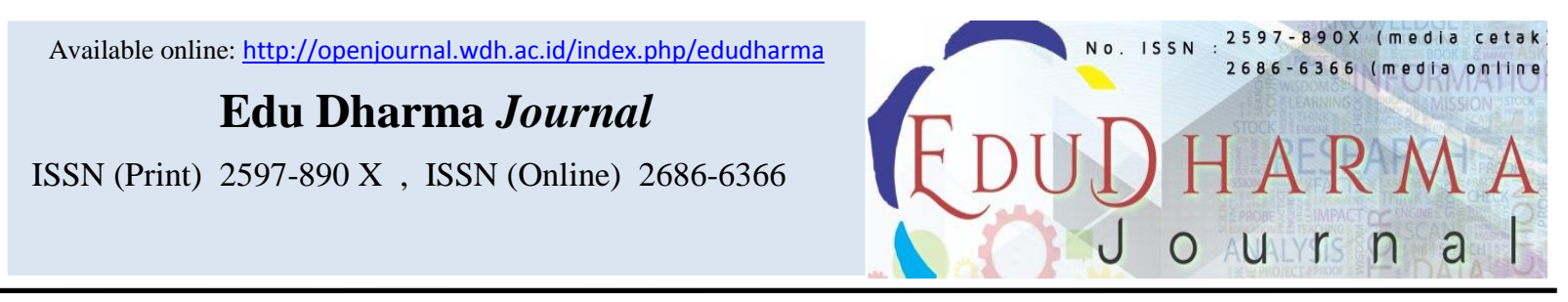

\title{
PEMBERIAN KOTAK OBAT HARIAN TERHADAP KEPATUHAN MENGKONSUMSI OBAT HIPERTENSI PADA PASIEN HIPERTENSI
}

\author{
Ratumas Ratih Puspita ${ }^{1 *}$, Rita Dwi Pratiwi ${ }^{2}$, Fenita Purnama Sari Indah ${ }^{3,}$ Delly Ema \\ Sandria Tambunan ${ }^{4,}$ Vika Ari Yuniar ${ }^{5}$ \\ 1,2,4,5 STIKes Widya Dharma Husada Tangerang, Jalan Pajajaran No.1, Pamulang, Tangerang Selatan 15417, Indonesia \\ ${ }^{3}$ STIKes Kharisma Persada, Jalan Pajajaran No.1, Pamulang, Tangerang Selatan 15417, Indonesia
}

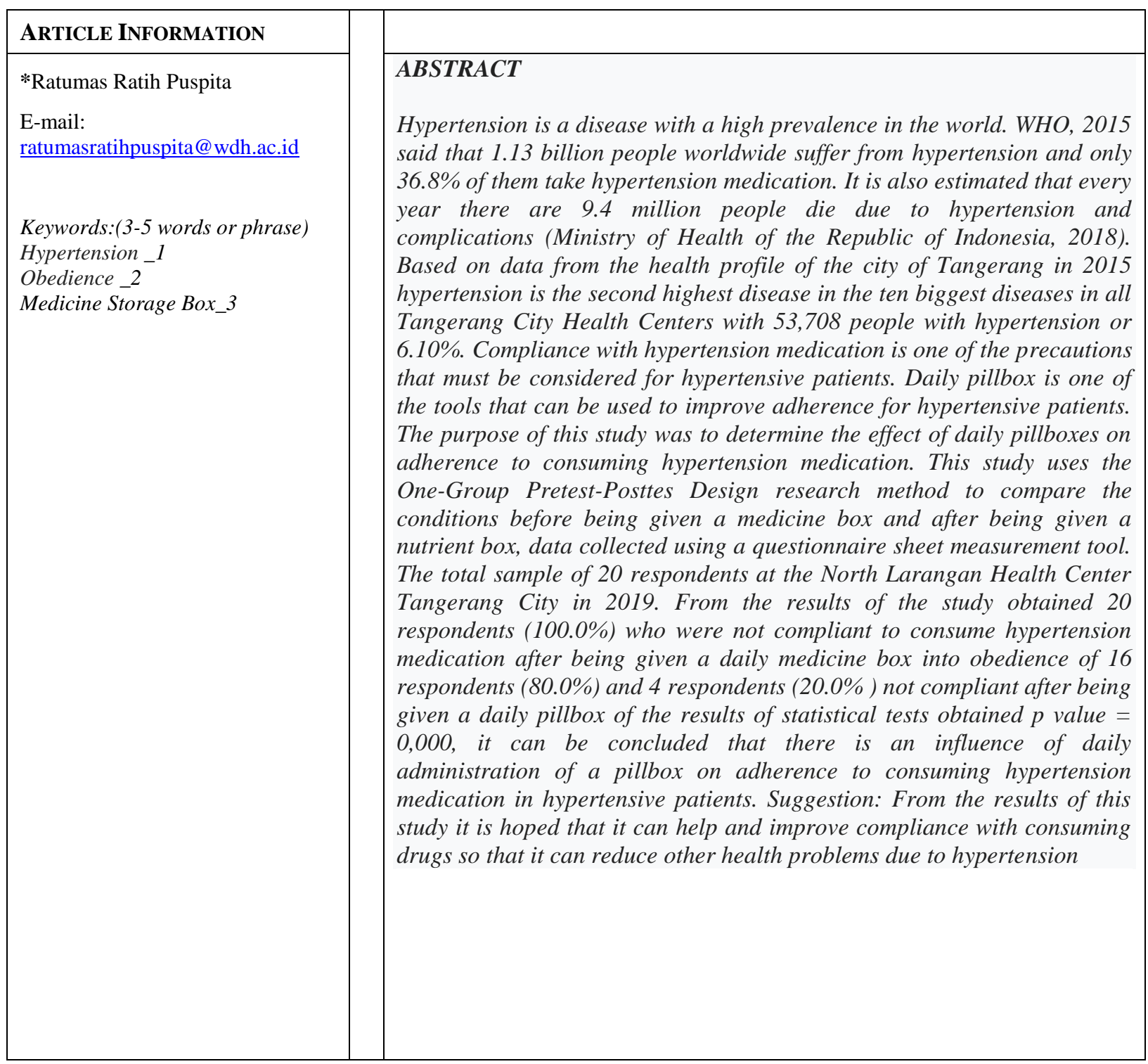




\begin{tabular}{|c|c|}
\hline $\begin{array}{l}\text { Kata Kunci: (3-5 kata atau frase) } \\
\text { Hipertensi_1 } \\
\text { Kepatuhan__2 } \\
\text { Kotak Obat_3 }\end{array}$ & $\begin{array}{l}\text { A B S T R A K } \\
\text { Hipertensi merupakan penyakit dengan prevelensi yang cukup tinggi di } \\
\text { dunia. WHO, } 2015 \text { mengatakan bahwa } 1,13 \text { miliar orang didunia } \\
\text { menderita hipertensi dan hanya } 36,8 \% \text { diantaranya yang minum obat } \\
\text { hipertensi.Diperkirakan juga setiap tahun ada } 9,4 \text { juta orang meninggal } \\
\text { akibat hipertensi dan komplikasi (KemenKes RI,2018). Berdasarkan data } \\
\text { profil kesehatan kota tangerang tahun } 2015 \text { hipertensi merupakan penyakit } \\
\text { terbanyak yang menduduki peringkat ke dua dari sepuluh penyakit terbesar } \\
\text { di semua puskesmas Kota Tangerang dengan jumlah penderita hipertensi } \\
\text { sebanyak 53,708 orang atau } 6,10 \% \text {. Kepatuhan mengkonsumsi obat } \\
\text { hipertensi merupakan salah satu pencegahan yang harus di perhatikan bagi } \\
\text { pasien hipertensi. Kotak obat harian adalah ssalah satu alat yang dapat } \\
\text { digunakan untuk meningkatkan kepatuhan bagi pasien hipertensi. Tujuan } \\
\text { dari penelitian ini adalah untuk mengetahui pengaruh kotak obat harian } \\
\text { terhadap kepatuhan mengkonsumsi obat hipertensi. Penelitian ini } \\
\text { menggunakan metode penelitian One-Group Pretest-Posttes Design untuk } \\
\text { membandingkan keadaan sebelum diberikan kotak obat dan sesudah di } \\
\text { berikan kotak obat haraian, data yang dikumpulkan menggunakan alat } \\
\text { ukur lembar kuesioner. Jumlah sampel sebanyak 20 responden di } \\
\text { Puskesmas Larangan Utara Kota Tangerang Tahun } 2019 \text {. Dari hasil } \\
\text { penelitian diperoleh 20 responden (100.0\%) yang tidak patuh } \\
\text { mengkonsumsi obat hipertensi setelah diberikan kotak obat harian menjadi } \\
\text { patuh sejumlah } 16 \text { responden (80.0\%) dan } 4 \text { responden (20.0\%) tidak } \\
\text { patuh setelah diberikan kotak obat harian hasil uji statistik diperoleh nilai p } \\
\text { = 0.000 maka dapat disimpulkan bahwa ada pengaruh pemberian kotak } \\
\text { obat harian terhadap kepatuhan mengkonsumsi obat hipertensi pada pasien } \\
\text { hipertensi. Saran : Dari hasil penelitian ini diharapkan dapat membantu } \\
\text { serta meningkatkan kepatuhan mengkonsumsi obat sehingga dapat } \\
\text { mengurangi masalah kesehatan lainnya akibat hipertensi }\end{array}$ \\
\hline & This is an open access article under the $\underline{\mathrm{CC}-\mathrm{BY}-\mathrm{NC}-\mathrm{SA} \text { license. }}$ \\
\hline & (C) 2020 Some rights reserved \\
\hline
\end{tabular}




\section{PENDAHULUAN}

Penyakit merupakan masalah kesehatan yang terjadi pada manusia dan harus dilakukan penanganan dan pengobatannya sehingga masalah kesehatan tersebut bisa teratasi. berbagai penyakit memiliki tingkat keparahan dan penanganan yang berbeda-beda, seperti penyakit diabetes mellitus, hipertensi, tb dan lain-lain. Beberapa penyakit tersebut mengharuskan penderita untuk mengkonsumsi obat dalam jangka waktu yang lama bahkan bisa seumur hidup. Hipertensi merupakan penyakit yang tidak bisa di disembuhkan namun bisa di atasi, seperti yang dikatakan Fitriani dan Okta (2014) bahwa hipertensi merupakan penyakit yang tidak dapat disembuhkan namun hanya dapat dikendalikan sehingga bagi seseorang yang telah menderita penyakit hipertensi untuk dapat mengendalikan tekanan darah dalam batas normal. Gaya hidup yang baik merupakan salah satu cara yang dapat dilakukan bagi penderita hipertensi, namun gaya hidup yang baik saja belum cukup bagi sebagian penderita hipertensi sehingga diperlukan untuk mengkonsumsi obat hipertensi. Pasien-pasien yang mengalami hipertensi berat memerlukan pengobatan jangka panjang, pemakaian obat dalam waktu yang lama, maka obat hipertensi harus diminum seumur hidup, tetapi setelah beberapa waktu dosis pemeliharaan dapat di turunkan ( Tjay dalam Chisty, 2010).

Data WHO (World Health Organization) tahun 2015 menunjukkan sekitar1,13 miliar orang didunia menderita hipertensi. Artinya 1 dari 3 orang di dunia terdiagnosis menderita hipertensi, hanya $36,8 \%$ di antaranya yang minum obat hipertensi. Prevalensi hipertensi di prediksiakan terus meningkat setiap tahunnya, di perkirakan pada tahun 2025 akan ada 1,5 milliar orang yang terkena hipertensi. Diperkirakan juga setiap tahun ada 9,4 juta orang meninggal akibat hipertensi dan komplikasi (KemenKes RI,2018). Berdasarkan hasil dari Riset Kesehatan Dasar (RisKesDas) Prevalensi hipertensi di Indonesia pada tahun 2018 mencapai $34,1 \%$. Prevalensi hipertensi ditentukan berdasarkan pengukuran tekanan darah pada penduduk mulai dari usia 18 tahun (KemenKes RI, 2017). Pada tahun 2018 hasil Riskesdas proporsi riwayat minum obat dan alasan tidak minum obat pada penderita hipertensi berdasarkan diagnosa dokter yaitu yang melakukan konsumsi obat hipertensi rutin sebesar $(54,4 \%)$, tidak mengkonsumsi obat hipertensi secara tidak rutin sebanyak $(32,3 \%)$ dan tidak mengkonsumsi obat hipertensi sebanyak (13,3\%). Berdasarkan 
data profil kesehatan Kota Tangerang tahun 2015 hipertensi merupakan penyakit terbanyak yang menduduki peringkat ke dua dari sepuluh penyakit terbesar di semua puskesmas Kota Tangerang dengan jumlah penderita hipertensi sebanyak 53,708 orang atau $6,10 \%$.

Keberhasilan pengobatan pada pasien hipertensi dipengaruhi oleh beberapa faktor, salah satu di antaranya adalah kepatuhan dalam mengonsumsi obat, sehingga pasien hipertensi dapat mengendalikan tekanan darah dalam batas normal (Evadewi Kenny, dkk 2013). Kepatuhan minum obat pada pasien hipertensi sangat lah penting karena tekanan darah dapat dikontrol dengan minum obat antihipertensi yang teratur, sehingga dalam jangka panjang risiko kerusakan organ- organ penting tubuh seperti otak, jantungdan ginjal dapat dikurangi (Aulia Rizki, 2018). Pasien yang berperilaku tidak patuh akan menghambat keberhasilan terapi bahkan menimbulkan kegagalan terapi pengobatan yang didapatkan ( Fauzi.R, dkk 2018). Dalam meningkatkan perilaku pasien untuk patuh mengkonsumsi obat hipertensi dapat menggunakan beberapa strategi yaitu berbasis teknologi dan memberikan alat bantu berupa kotak obat harian. Satu kotak obat yang diberikan kepada pasien dapat terisi 7 obat dengan diberikan skat atau pembatas dan label yang bertuliskan namanama hari, angka 1-7 sehingga pasien hipertensi cukup membawa satu kotak obat harian namun bisa untuk menaruh obat selama 7 hari dan dapat mencegah terjadinya ketidakpatuhan dalam mengkonsumsi obat harian hipertensi. Sehingga tujuan dari terapi obat hipertensi dapat tercapai. Seperti yang dikatakan oleh Winasthing Dianing Y.M (2010) Pemberian informasi disertai alat bantu ketaatan berupa kotak obat dan label kepatuhan akan lebih mempermudah pemberian informasi dan meningkatkan pemahaman pasien tentang penggunaan obat yang tepat. Dengan label kepatuhan, pasien akan lebih mudah mengingat penggunaan obat yang teratur dan benar, alat bantu berupa kotak obat akan membantu pasien untuk lebih taat dalam menggunakan obat. Berdasarkan survei awal yang dilakukan pada Rabu, 09 Januari 2019 dengan cara observasi yaitu terdapat banyak pasien yang datang untuk berobat dan mayoritas lansia. Berdasarkan hasil wawancara terbuka yang dilakukan kepada delapan lansia penderita hipertensi. Dua pasien hipertensi mengatakan minum obat hipertensi rutin dan rutin cek kepuskesmas, empat pasien hipertensi mengatakan tidak rutin minum obat 
dengan alasan lupa dan dua pasien hipertensi mengatakan tidak rutin cek ke puskesmas. Penelitin ini untuk mengidentifikasi pengaruh pemberian kotak obat harian terhadap kepatuhan mengkonsumsi obat hipertensi pada pasien hipertensi di puskesmas larangan utara kota tangerang tahun 2019.

\section{METODE PENELITIAN}

Jenis penelitian ini adalah kuantitatif dengan desain penelitian One-Group Pretest-Posttes Design. Penelitian ini dilakukan untuk mengetahui pengaruh pemberian kotak obat harian terhadap kepatuhan mengkonsumsi obat hipertensi pada pasien hipertensi. Populasi yang akan digunakan pada penelitian ini adalah penderita hipertensi yang tidakpatuh minum obat pada bulan September Desember 2018 berjumlah 20 orang. Dalam penelitian ini sampel menggunakan metode non probability sampling dengan teknik sampling jenuh yaitu seluruh jumlah populasi dijadikan sampel berjumlah 20 orang dengan kriteria inklusi yaitu responden yang menderita hipertensi, responden yang tidakpatuh mengkonsumsi obat hipertensi, responden yang berobat ke puskesmas Laranagan Utara Kota Tangerang, responden yang mendapatkan obat antihipertensi, responden yang bersedia menjadi sampel, dan dapat bekerjasama secara sukarela dan kriteria eksklusi yaitu responden patuh mengkonsumsi obat antihipertensi, tidak bersedia menjadi responden dan

Instrument yang digunakan dalam penelitian ini adalah alat bantu berupa kotak obat harian kuesioner yang digunakan untuk melihat skor kepatuhan. Kuesioner ini akan dibagikan kepada responden yang sesuai dengan kriteria inklusi. Pengumpulan data dilaksanakan di Puskesmas Larangan Utara Kota Tangerang dengan cara melakukan pendekatan dengan responden dan apabila responden setuju untuk menjadi responden maka peneliti meminta kesediaan responden untuk menandatangani lembar persediaan menjadi responden, responden diberikan penjelasan tentang cara mengisi kuesioner dan cara menggunakan kotak obat, pengisian kuesioner dilakukan sebelum dan sesudah diberikan kotak obat selama 2 minngu. Dan responden dipersilahkan bertanya jika belum jelas, selama mengisi kuesioner ataupun cara menggunakan kotak obat, pada saat pengisian kuesioner peneliti berada didekat responden untuk mengantisipasi pertanyaan akan ketidakjelasaan responden, setelah mengisi kuesioner, maka peneliti mengambil kuesioner yang 
ada pada responden kemudian dikumpulkan oleh peneliti, daftar pertanyaan yang telah dilengkapi jawaban dikumpulkan untuk pengelolahan data melalui proses tabulasi dan kemudian dianalisa dengan alat bantu komputer. Penelitian ini menganalisis distribusi frekuensi karakteristik responden yaitu jenis kelamin, frekuensi usia, frekuensi pendidikan trakhir dan frekuensi pekerjaan. Dan menganalisis distribusi frekuensi kepatuhan pre intervensi dan frekuensi kepatuahn post intervensi. Analisis bivariat pada penelitan ini menggunakan uji wilcoxon, yaitu untuk melihat pengaruh pemberian kotak obat harian terhadap kepatuhan mengkonsumsi obat hipertensi pada pasien hipertensi. Penelitian ini disesuaikan dengan etik penelitian yaitu penelitian yang dihasilkan dapat memberikan manfaat dan mempertimbangkan antara aspek resiko dengan aspek manfaat, bila penelitian yang dilakukan dapat mengalami dilema dalam etik, manusia memiliki hak dan merupakan makhluk yang mulia yang harus di hormati, karena manusia untuk diikutsetakan menjadi subjek penelitian, menghargai hak atau memberikan pengobatan secara adil, hak menjaga privasi manusia, dan tidak berpihak dalam perlakuan terhadap manusia.

\section{HASIL PENELITIAN}

Tabel 1. Distribusi Frekuensi Responden Berdasarkan Jenis Kelamin, Usia, Pendidikan Terakhir dan Pekerjaan

\begin{tabular}{lc}
\hline Karakteristik & Hasil \\
\hline Jenis kelamin & \\
Laki- laki & \\
Perempuan & $4(20.0 \%)$ \\
Usia $\quad 16(80.0 \%)$ \\
$\quad$ 34-53 Tahun & $7(35.0 \%)$ \\
$\quad>$ 54 Tahun & $13(65.0 \%)$ \\
Pendidikan Trakhir & \\
Pendidikan Rendah & $12(60.0 \%)$ \\
Pendidikan Tinggi & $8(40.0 \%)$ \\
Pekerjaan & \\
Bekerja & \\
Tidak Bekerja & $4(20.0 \%)$ \\
\hline
\end{tabular}

Tabel 1 menjelaskan bahwa karakteristik responden dengan jenis kelamin sebagian besar responden berjumlah 16 dengan presentase $(80.0 \%)$ berada pada kelompok perempuan, frekuensi usia bahwa lebih dari setengahnya responden berjumlah 13 dengan presentase $(65.0 \%)$ berada pada kelompok usia >54 tahun, frekuensi pendidikan trakhir bahwa lebih dari setengahnya responden berjumlah 12 responden dengan presentase $(60.0 \%)$ berada pada kelompok pendidikan rendah dan frekuensi pekerjaan bahwa sebagian besar responden berjumlah 16 dengan presentase $(80.0 \%)$ berada pada kelompok tidak bekerja. 
Tabel 2. Distribusi Frekuensi Responden Berdasarkan Kepatuhan Pre Intervensi

\begin{tabular}{lll}
\hline Kepatuhan & $\mathrm{n}$ & $\%$ \\
\hline Tidak Patuh & 20 & $100,0 \%$ \\
\hline Patuh & 0 & $0,0 \%$ \\
\hline
\end{tabular}

Tabel 2 menjelaskan frekuensi responden berdasarkan kepatuhan pre intervensi bahwa seluruh responden berjumlah 20 dengan presentase $(80.0 \%)$ berada pada kelompok tidak patuh.

Tabel 3. Distribusi Frekuensi Responden Berdasarkan Kepatuhan Post Intervensi

\begin{tabular}{ccc}
\hline Kepatuhan & $\mathrm{n}$ & $\%$ \\
\hline Tidak Patuh & 4 & $20,0 \%$ \\
Patuh & 16 & $80,0 \%$ \\
\hline
\end{tabular}

Tabel 3 menjelaskan frekuensi responden berdasarkan kepatuhan post intervensi bahwa bahwa sebagian besar responden berjumlah 16 dengan presentase $(80.0 \%)$ berada pada kelompok patuh.

Tabel 4. Pengaruh Pemberian Kotak Obat Harian Terhadap Kepatuhan Mengkonsumsi Obat Hipertensi Pada Pasien Hipertensi

\begin{tabular}{lccll}
\hline $\begin{array}{l}\text { Kotak } \\
\text { Obat } \\
\text { Harian }\end{array}$ & $\mathrm{N}$ & $\begin{array}{l}\text { Mean } \\
\text { Rank }\end{array}$ & $\begin{array}{l}\text { Sum } \\
\text { Of } \\
\text { Rank }\end{array}$ & $\begin{array}{l}P \\
\text { value }\end{array}$ \\
\hline $\begin{array}{l}\text { Pre } \\
\text { Intervensi }\end{array}$ & $0^{\mathrm{a}}$ & .00 & .00 & \\
$\begin{array}{l}\text { Post } \\
\begin{array}{l}\text { Intervensi } \\
\text { (Ties) }\end{array}\end{array}$ & $16^{\mathrm{b}}$ & 8.50 & 136.00 & 0,000 \\
\hline
\end{tabular}

Tabel 4 menjelaskan bahwa terdapat pengaruh pemberian kotak obat harian terhadap kepatuhan mengkonsumsi obat hipertensi pada pasien hipertensi dengan hasil $p$ value 0.000

\section{PEMBAHASAN}

Tabel 1 menjelaskan bahwa jenis kelamin sebagian besar responden berjumlah 16 dengan presentase $(80.0 \%)$ berada pada kelompok perempuan. Secara teori yang disampaikan oleh Depkes RI, 2013 dalam hal menjaga kesehatan, biasanya kaum perempuan lebih memperhatikan kesehatannya dibandingkan dengan lakilaki. Perbedaan pola perilaku sakit juga dipengaruhi oleh jenis kelamin, perempuan lebih sering mengobatkan dirinya dibandingkan laki-laki, sehingga akan lebih banyak perempuan yang datang berobat dibandingkan laki-laki (Notoatmodjo,2010). Hal ini tidak sejalan dengan hasil penelitian yang dilakukan oleh Saepudin dkk (2011) yang menunjukkan bahwa tidak ada hubungan antara jenis kelamin dengan kepatuhan penggunaan obat pada pasien hipertensi. Hal ini juga sejalan dengan hasil penelitian yang dilakukan oleh puspita exa tahun 2016 bahwa tidak ada hubungan yang signifikan antara jenis kelamin dengan kepatuhan dalam pengobatan hipertensi $\mathrm{P}$ $=0,366 \quad(\mathrm{P}>0.05 \%) . \quad$ Peneliti menyimpulkan bahwa berdasarkan teori 
yang ada tidak sejalan dengan hasil penelitian yang dimiliki oleh peneliti hal ini dikarenakan usia responden lebih banyak berjumlah $>50$ tahun .

Tabel 1 menjelaskan bahwa usia lebih dari setengahnya responden berjumlah 13 dengan presentase $(65.0 \%)$ berada pada kelompok usia >54 tahun Secara konsep kepatuhan menurut Niven dalam Iswanti tahun 2012 bahwa seseorang yang memiliki usia muda lebih patuh dari usia tua. Hal ini mungkin karena usia muda memiliki kapasitas dan fungsi memori yang lebih baik untuk menerima informasi tentang pengobatan. Konsep ini di dukung oleh Fleischhacker 2003 bahwa usia lanjut lebih tidakpatuh dikarenakan proses degeneratif pada kapasitas memori yang dialaminya. Hal ini berbeda dengan pendapat Fittharia 2014 bahwa usia merupakan suatu tingkat kematangan dan kekuatan seseorang akan lebih matang dalam berfikir dan teratur dalam melaksanakan pengobatan. Namun bias saja mereka yang usia muda lebih patuh dari usia tua atau sebaliknya usia tua lebih patuh dari usia muda. Hal ini bisa disebabkan oleh tingkat pendidikan dan pengetahuan respon yang berbeda-beda dan disertai juga respon yang diberikan penderita hipertensi terhadap masalah kesehatan yang berbeda-beda. Hasil penelitian ini tidak sejalan dengan teori yang disampaikan oleh Niven dalam Iswanti 2012 bahwa usia muda lebih patuh dibandingkan dengan usia tua. Tetapi hasil penelitian ini sejalan dengan Fitrina 2014 bahwa yang berusia muda awal lebih patuh dalam menjalani pengobatan, ini disebabkan karena responden mementingkan kesehatannya. Dan sebaliknya bagi responden yang berusia dewasa akhir kurang atau tidak patuh dalam menjalani pengobatan, ini disebabkan karena responden tidak mengerti dan tidak mementingkan kesehatannya. Hal ini didukung oleh penelitian yang dilakukan Liberty 2010 bahwa tidak ada pengaruh yang signifikan antara usia dengan kepatuhan dalam menjalankan pengobatan hipertensi. Peneliti menyimpulkan bahwa dalam penelitian ini usia lanjut memiliki tingkat kepatuhan yang kurang hal ini disebabkan karena usia lanjut memiliki banyak perubahan fisik maupun fungsiologi. Banyak nya faktor yang mempengaruhi penurunan pada tubuhnya menyebabkan usia lanjut memiliki kepatuahan yang kurang dibandingan dengan usia dewasa akhir.

Tabel 1 menjelaskan bahwa pendidikan trakhir lebih dari setengahnya responden berjumlah 12 responden dengan presentase 
$(60.0 \%)$ berada pada kelompok pendidikan rendah. Secara teori menurut Lawrence Green dalam Puspita Exa 2016 menyatakan bahwa perilaku patuh dipengaruhi oleh faktor-faktor predisposisi, salah satunya pendidikan. Teori lain juga di jelaskan oleh Sugiharto dkk (2003) bahwa Responden yang berpendidikan lebih tinggi akan mempunyai pengetahuan yang lebih luas dibandingkan dengan responden yang tingkat pendidikanya rendah. Menurut penelitian yang dilakukan Ekarini (2011) dan Mubin dkk (2010) menunjukan tingkat pendidikan berhubungan dengan tingkat kepatuhan pasien hipertensi dalam menjalani pengobatan. Responden yang memiliki tingkat pengetahuan yang tinggi sebagian besar memiliki kepatuhan dalam menjalani pengobatan. Hal ini sejalan dengan hasil penelitian Puspita Exa 2016 kategori tidak patuh adalah mereka yang berpendidikan rendah yaitu sebesar 42 responden (65,6\%), sedangkan pada responden dengan pendidikan tinggi $85 \%$ patuh dalam menjalani pengobatanya. Hal ini diperkuat oleh hasil penelitian yang dilakukan Fitrina 2014 bahwa adanya hubungan pendidikan dengan kepatuhan klien hipertensi dalam menjalani pengobatan di Puskesmas Talang Kabupaten Solok. Bahwa responden yang berpendidikan tinggi lebih patuh menjalani pengobatan dikarenakan responden menyadari dan mengetahui lebih mementingkan kesehatan guna untuk kelangsungan hidup, sebaliknya pada responden yang berpendidikan rendah kurang patuh atau tidak patuh dalam patuh menjalani pengobatan. Peneliti dapat menyimpulkan bahwa pendidikan merupakan salah satu faktor yang sangat penting untuk menentukan perilaku kepatuhan. Dari pendidikan seseorang mendapatkan pengetahuan yang baik sehingga dapat menerima infomasi yang benar maka dapat berperilaku yang benar sehingga mampu meningkatkan kualitas hidup baik dan dalam penelitian ini membuktikan bahwa responden dengan pendidikan rendah sangat berisiko untuk tidak patuh dalam menjalani pengobatan sehingga pendidikan menjadi salah satu faktor untuk meningkatkan kepatuhan.

Tabel 1 menjelaskan bahwa pekerjaan sebagian besar responden berjumlah 16 dengan presentase $(80.0 \%)$ berada pada kelompok tidak bekerja. Secara teori menurut Pujasari Ajeng,dkk (2015) Pekerjaan merupakan faktor kepatuhan. Pasien yang bekerja cenderung tidakpatuh dibandingkan dengan pasien yang tidak bekerja, hal ini disebabkan pasien yang bekerja tidak memiliki waktu untuk 
menuju pelayanan kesehatan. Hal ini tidak sejalan dengan teori perempuan dalam Hairunisa 2014 bahwa yang bekerja sebagai ibu rumah tangga adalah motivator yang baik bagi suami dan anak-anak nya terutama dalam hal kesehatan, tetapi dukungan untuk dirinya sendiri masih kurang. Sehingga ketidakpatuhan pada pekerja ibu rumah tangga dapat terjadi akibat kurangnya motivasi bagi dirinya sendiri. Pada Penelitian ini mayoritas terjadi pada perempuan dengan usia $>50$ tahun sehingga kategori tidak bekerja lebih banyak dibandingkan dengan kategori bekerja. Hal ini sejalan dengan hasil penelitian yang dilakukan Mbakurawang 2014 bahwa tidak terdapat hubungan antara pekerjaan dengan kepatuhan minum obat antihipertensi. Hal ini diperkuat dengan penelitian yang dilakukan Puspita Exa 2016 bahwa tidak ada hubungan yang signifikan antara yang tidak bekerja (61.9\%) dangan yang bekerja $(38,1 \%)$. Peneliti menyimpulkan bahwa karena dalam penelitian ini mayoritas terjadi pada usia >50 tahun dan pada perempuan sehingga responden lebih banyak yang tidak bekerja maka status pekerjaan belum tentu memiliki prilaku kepatuhan yang baik dalam kepatuhan pengobatan hipertensi. Akan tetapi dapat dipengaruhi oleh faktor lainnya.
Tabel 2 menjelaskan frekuensi responden berdasarkan kepatuhan pre intervensi bahwa seluruh responden berjumlah 20 dengan presentase $(80.0 \%)$ berada pada kelompok tidak patuh. Hal ini sesuai dengan teori yang sampaikan oleh Lam, dkk 2015 dalam Fauzi.R, dkk 2018:37 metode penilaian kepatuhan pasien ini telah mencapai seri yang kedelapan yang dikenal dengan nama Eight-Item Morisky Medication Adherence Scale (MMAS-8). Metode ini berisikan 7 macam pertanyaan pasif dan 1 pertanyaan panjang. Pertanyaan ini akan berfokus pada perilaku pasien selama pengobatan dan faktor-faktor yang mempengaruhi kepatuhan dalam pengobatan seperti kelupaan (Lam, dkk 2015 dalam Fauzi.R, dkk 2018:37). Total skor dari pertanyaan akan menggambarkan tingkat kepatuhan pasien dalam penggunaan obatnya. Metode MMAS-8 ini memiliki validitas dan reliabilitas yang tinggi, khususnya pada saat penilaian pasien dengan penyakit kronis. Metode ini dapat mengidentifikasi ketidakpatuhan pasien dalam pengobatan. Sehingga metode ini paling sesuai digunakan dalam pelayanan klinik untuk skrining awal kepatuhan pasien (X, Tan, dkk 2014 dalam Fauzi.R, dkk 2018:37). Peneliti menyimpulkan bahwa penggunakan kuesioner MMAS-8 ini dapat 
menghasilkan skor kepatuhan. Sehingga melalui hasil skor yang didapatkan bisa ditarik kesimpulan apakah responden patuh atau tidak. Dalam penelitin ini sebelum di berikan hasil intervensi (pre) 20 responden $(100.0 \%)$ tidak patuh dengan nilai skor > 4.

Tabel 3 menjelaskan frekuensi responden berdasarkan kepatuhan post intervensi bahwa sebagian besar responden berjumlah 16 responden dengan presentase $(80.0 \%)$ memiliki perubahan perilaku menjadi patuh untuk mengkonsumsi obat hipertensi dan sebagian kecil responden berjumlah 4 responden dengan presentase (20.0\%) tidak memiliki perubahan setelah diberikan intervensi berupa kotak obat harian sehingga tetap tidak patuh untuk mengkonsumsi obat hipertensi. Hal ini sejalan dengan teori yang disampaikan oleh Fauzi.R, dkk 2018:49 tahapan yang dapat dilakukan untuk meningkatkan kepatuhan pasien salah satunya adalah menggunakan alat pembantu managemen obat seperti pill container atau kotak obat harian Didesain untuk skala mingguan, alat ini akan memudahkan perjalanan jauh yang bisa meningkatkan risiko faktor kelupaan menggunakan obat-obatan (MacLaughlin, dkk 2005) dalam Fauzi.R, dkk (2018:49). Peneliti menyimpulkan walaupun terdapat 4 responden $(20,0 \%)$ yang tidak berubah kepatuhannya setelah diberikan kotak obat harian namun skor ketidakpatuhannya berkurang. Hal ini diperkuat dari hasil wawancara yang dilakukan oleh peneliti dan hasil penghitungan skor dari kuesioner yang diisi oleh responden.

Tabel 4 menjelaskan bahwa terdapat pengaruh pemberian kotak obat harian terhadap kepatuhan mengkonsumsi obat hipertensi pada pasien hipertensi dengan hasil $p$ value 0.000 . Hal ini sejalan dengan teori yang disampaikan Winasthing Dianing Y.M 2010 bahwa Pemberian informasi disertai alat bantu ketaatan berupa kotak obat dan label kepatuhan akan lebih mempermudah pemberian informasi dan meningkatkan pemahaman pasien tentang penggunaan obat yang tepat. Dengan label kepatuhan, pasien akan lebih mudah mengingat penggunaan obat yang teratur dan benar, alat bantu berupa kotak obat akan membantu pasien untuk lebih taat dalam menggunakan obat. Hal ini diperkut oleh McNaughton David, 2012 mengatakan telah diciptakan sebuah alat yang di sebut pill box, cukup efektif untuk mengatasi masalah ketaatan terhadap konsumsi obat-obatan yang rutin selain efektif, pill box di nilai dapat membantu para lansia yang memiliki keluhan hipertensi, diabetes, atau penyakit lain 
yang memerlukan konsumsi obat-obatan setiap hari. Hal ini sejalan dengan hasil penelitian yang dilakukan P.W. Macintosh, dkk 2007 bahwa tingkat kepatuhan pasien yang menggunakan kotak obat harian sebanyak $81 \%$ dan yang menggunakan botol pill konvensional sebanyak $86 \%$, namun lebih banyak pasien yang puas dengan kotak obat harian yaitu $61 \%$ dibandingkan dengan botol pill konvensional yaitu $11 \%$ dan berfikir bahwa kotak obat harian lebih membantu dalam meningkatkan kepatuhan minum obat sebanyak 50\% dari pada menggunakan botol pill konvensional sebanyak $11 \%$ menurut. Penelitian lain juga dilakukan oleh Sammulia Suci, dkk 2016 tentang penggunaan pill box dengan 50 responden didapatkan hasil, kategori patuh yaitu sebanyak 35 responden (70.0\%) dan tidak patuh yaitu sebanyak 15 responden $(30.0 \%)$. Dengan demikian alat bantu berupa kotak obat akan meningkatkan ketaatan dan dampak terapi, selain itu akan mengurangi biaya terapi serta meningkatkan kualitas hidup pasien. Peneliti menyimpulkan bahwa penggunakan alat bantu berupa kotak obat harian dapat meningkatkan kepatuhan sehingga dapat membantu para pasien yang memerlukan konsumsi obat-obatan dalam jangka panjang seperti hipertensi .
Hal ini diperkuat dari hasil wawancara yang peeneliti lakukan kepada 16 responden yang patuh setelah diberikan kotak obat harian, yang mengatakan bahwa kotak obat harian yang diberikan mampu mengurangi perilaku kelupaan dan mudah dibawa kemana-mana pada saat berpergian sehingga mampu meningkatkan perilaku patuh mengkonsumsi obat.

\section{KESIMPULAN}

1. Hasil data demografi berdasarkan karakteristik : jenis kelamin responden sebagian besar perempuan sebanyak 16 responden $(80.0 \%)$, usia responden sebagian besar usia lanjut >54 tahun $(65.0 \%)$, status pekerjaan sebagaian besar responden tidak bekerja karena rata-rata ibu rumah tangga dan pensiunan sebanyak 12 responden (80.0\%) responden, pendidikan trakhir responden sebagian besar responden berpendidikan rendah karena rata-rata SD dan SMP sebanyak 12 responden $(60.0 \%)$.

2. Hasil gambaran karakteristik terkait kepatuhan sebelum diberikan intervensi berupa kotak obat harian sebagian besar responden tidak patuh dalam mengkonsumsi obat sebanyak 20 responden (100.0\%). 
3. Hasil gambaran karakteristik terkait kepatuhan setelah diberikan intervensi berupa kotak obat harian sebagian besar responden memiliki peningkatan perilaku patuh dalam mengkonsumsi obat sebanyak 16 responden $(80.0 \%)$.

4. Hasil uji Wilcoxon menunjukkan bahwa terdapat pengaruh pemberian kotak obat harian terhadap kepatuhan mengkonsumsi obat hipertensi pada pasien hipertensi di puskesmas larangan utara kota tangerang tahun 2019 dengan nilai $p$-value $0,000<\alpha=$ 0,05 sehingga dapat disimpulkan adanya pengaruh pemberian kotak obat dengan kepatuhan mengkonsumsi obat hipertensi.

\section{DAFTAR PUSTAKA}

Alfian, Riza. (2014). Layanan pesan singkat pengingat untuk meningkatkan kepatuhan dan menurunkan tekanan darah pasien hipertensidi rsud dr. h. moch ansari saleh banjarmasin. Akademi Farmasi ISFI Banjarmasin, Indonesia. Diakses Pada Tanggal 03 Maret 2019

Aulia Rizki. (2018). Pengaruh Pengetahuan Terhadap Kepatuhan Pasien Hipertensi Di Instalasi Rawat Jalan RSUD Dr. Moewardi. Surakarta Periode Februari-April 2018. Universitas Muhammadiyah Surakarta. Diakses Pada Tanggal 15 Januari 2019

Ardhiyanti Yulrina, Lusina Novita dan Megasari Kiki. (2015). Bahan Ajar
AIDS Pada Asuhan Kebidanan. Yogyakarta. Deepublish

Aspiani Yuli Reni. (2014). Buku ajar asuhan keperawatan geontik, aplikasi nanda, nic dan noc-jilid 1. Jakarta Timur : TIM

Christy Dessy. (2010). Gambaran pengobatan hipertensi pada pasien rawat inap di rumah sakit umum pusa Dr. Soeradji Tirtonegoro Klaten periode Januari-Juni tahun 2009. Universitas Muhammadiyah Surakarta. Diakses Pada Tanggal 11 Mei 2019

Evadewi Kenny R. P dan Sukamayati S Made Luh. (2013). Kepatuhan Mengkonsumsi Obat Hipertensi Di Denpasar Ditinjau Dari Kepribadian Tipe A dan Tipe B. Universitas Udayana. Diakses Pada Tanggal 14 Januari 2019

Fauzi Romdlon dan Nisha Khairul. (2018). Apoteker hepat, terapi taat, pasien sehat panduan simpel mengelola kepatuhan terapi. Yogyakarta : Stiletto Indie Book

Fithria,dkk. (2014). Faktor - faktor yang berpengaruh dengan kepatuhan berobat pada penderita hipertensi di klinik sumber sehat indrapuri aceh besar. Vol 5, No 2, 2014, ISSN : 2087-2879. Diakses Pada Tanggal 11 Mei 2019

Fitriani Yossi dan Harysko Rian Okta. (2014). Hubungan karakteristik dan motivasi pasien hipertensi terhadap kepatuhan dalam menjalani pengobatan di puskesmas talang kabupaten solok tahun 2014. Stikes Yarsi Sumba. Diakses Pada Tanggal 14 Januari 2019

Iswanti, Indah D. (2012). Pengatuh terapi 
perilaku modeling partisipan terhadap kepatuhan minum obat pada klien penatalaksanaan regimen terapeutik tidak efektif di RSUD Dr. Amino Gondo Hutomo Serang. Universitas Indonesia. Diakses Pada Tanggal 11 Mei 2019

Kemenkes. (2018). Hipertensi Membunuh Diam-Diam, Ketahui Tekanan Darah Anda dalam http://www.depkes.go.id/article/view /1805160004/hipertensi-membunuhdiam-diam-ketahui-tekanan-darahanda.html. Diakses Pada Tanggal 07 Februari 2019

Khoiriyyah Amilatul, dkk. (2015). Pengaruh buku harian untuk meningkatkan kepatuhan pada pasien hipertensi: studi kuasi eksperimen pada pasien hipertens. Vol 4, No 1. Universitas Diponerogo. Diakses Pada Tanggal 05 Februari 2019

Larasati. (2018). Pengaruh rebusan air daun salam terhadap penurunan kadar kolestrol pada warga rw 05 cerug bojongsari depok. Skripsi STIKes Widya Dharma Husada. Tangerang Selatan

Lestari, Deti D. (2015). Pengaruh pendidikan kesehatan dan sms reminder terhadap kepatuhan ibu hamil dalam mengkonsumsi tablet besi di wilayah kerja puskesmas pisangan tahun 2015. Skripsi. Universitas Islam Negeri Syarif Hidayatullah Jakarta

Macintosh. P.W, dkk. (2007). A Compatison Of Patient Adherence And Preference Of Packaging Method For Oral Anticancer Agents Using Conventional Pill Bottles Versus Daily Pill Boxes https://www.ncbi.nlm.nih.gov/m/pub med/17587364/. WOL. Diakses pada
17 Maret 2019.

Manurung Nixson. (2018). Keperawatan medikal bedah, komsep, mind mapping dan nanda nic noc, solusi cerdas lulus ukom bidang keperawatan - jilid 2. Jakarta : TIM

Notoatmodjo Soekidjo. (2018). Metodologi penelitian kesehatan. Jakarta : Rineka Cipta Sari Indah Nur Yanita . Jakarta : Bumi Medika

Porter, K, Angela, dkk. (2014). Impact of a pill box clinic to improve systolic blood pressure in veterans with uncontrolled hypertension taking 3 or more antihypertensive medications. JMCP

Priyono Nurjana Putri. (2018). Hubungan kesembuhan dengan kepatuhan minum obat pada penderita tuberkulosis paru di wilayah kerja puskesmas jambe kabupaten tangerang. Skripsi. STIKes Widya Dhara Husada. Tangerang Selatan

Pujasari, Ajeng. (2015). Faktor-faktor internal ketidakpatuhan pengobatan hipertensi di puskesmas kedungmunpun kota semarang. Vol 3, No 3, April 2015, ISSN: 23563346. Diakses Pada Tanggal 02 April 2019

Puspita, Exa. (2016). Faktor-faktor yang berhubungan dengan kepatuhan penderita hipertensi dalam menjalani pengobata. Skripsi. Universitas Negri Semarang. Diakses pada tanggal 8 Mei 2019

Sammulia Suci Fitriani, Rahmawati Fita, Andayani Tri Murti. (2016). Perbandingan pill box dan medication chart dalam meningkatkan kepatuhan dan outcome klinik geriatri kota batam. 
Universitas Gadjah Mada

Yogyakarta

Souza dan Santana. (2013)

etd.repository.ugm.ac.id/downloadfil e/99008/.../S2-2016-372975-

introduction.pdf. Diakses Pada Tanggal 17 Januari 2019

Sugiono. (2018). Metode penelitian kuantitatif. Bandung : PT Alfabeta

Winasthing Dianing Yesia Maria. (2010). Pengaruh Pemberian Alat Bantu Ketaatan dan Informasi Saat Home Visit Pada Perilaku Pasien ISPA Puskesma Kalibawang Periode JuniJuli 2010. Skripsi. Univeritas Sanata Dharma. Diakses Pada Tanggal 25 Januari

Yuandari Esti dan Aditya Rahman Topan, R. (2017). Metodologi penelitian dan statistik. Bogor : In Media 